\title{
Fungal and Bacterial Endophytes as Microbial Control Agents for Plant-Parasitic Nematodes
}

\author{
K. Kiran Kumar ${ }^{1}$ and Surendra K. Dara ${ }^{2, *(D)}$ \\ 1 ICAR-Central Citrus Research Institute, Nagpur 440033, Maharashtra, India; Kiran.Kommu@icar.gov.in \\ 2 University of California Cooperative Extension, 2156 Sierra Way, Ste. C, San Luis Obispo, CA 93401, USA \\ * Correspondence: skdara@ucdavis.edu
}

Citation: Kumar, K.K.; Dara, S.K. Fungal and Bacterial Endophytes as Microbial Control Agents for Plant-Parasitic Nematodes. Int. J. Environ. Res. Public Health 2021, 18, 4269. https://doi.org/10.3390/ ijerph18084269

Academic Editors: David Nichols and Paul Tchounwou

Received: 20 March 2021

Accepted: 15 April 2021

Published: 17 April 2021

Publisher's Note: MDPI stays neutral with regard to jurisdictional claims in published maps and institutional affiliations.

Copyright: (c) 2021 by the authors. Licensee MDPI, Basel, Switzerland. This article is an open access article distributed under the terms and conditions of the Creative Commons Attribution (CC BY) license (https:/ / creativecommons.org/licenses/by/ $4.0 /)$.

\begin{abstract}
Endophytes are symbiotic microorganisms that colonize plant tissues and benefit plants in multiple ways including induced systemic resistance to biotic and abiotic stresses. Endophytes can be sustainable alternatives to chemical nematicides and enhance plant health in a variety of cropping and natural environments. Several in vitro and in vivo studies demonstrated the potential of multiple species of Fusarium and Bacillus against plant-parasitic nematodes in horticultural, agricultural, and fodder crops and in forestry. While there were efforts to commercialize some of the endophytes as bionematicides, a lack of good formulations with consistent field efficacy has been a major hurdle in commercializing endophytes for nematode control. Identification of efficacious and environmentally resilient strains, a thorough understanding of their modes of action, interactions with various biotic and abiotic factors, and developing strategies that improve their effectiveness are critical areas to advance the commercialization of bionematicides based on fungal and bacterial endophytes.
\end{abstract}

Keywords: endophyte; bacteria; fungi; plant-parasitic nematode; bionematicide

\section{Introduction}

Plant-parasitic nematodes (PPN) such as root-knot nematodes (Meloidogyne spp.), cyst nematodes (Heterodera spp. and Globodera spp.), and root lesion nematodes (Pratylenchus spp.) are important pests of many crops around the world causing significant yield losses. They primarily attack the root system by forming feeding sites such as, single giant cells, syncytia, non-hypertrophied nurse cells and coenocytes, which provide a protective feeding environment [1]. PPN feeding causes root deformity, stunting of plants, yellowing of leaves, and yield reduction. Additionally, PPN also act as entry ways for secondary pests and pathogens by causing wounds in the plant roots [2]. It is estimated that PPN cause an average yield loss of $12.6 \%$ equal to USD 215.8 billion in 20 major commercial crops including banana, coconut, peanut, potato, rice and sugarcane around the world [3]. While the root-knot and cyst nematodes are sedentary, root lesion nematodes, the burrowing nematode (Radopholus similis), the stem nematode (Ditylenchus dipsaci), and the reniform nematode (Rotylenchulus reniformis) are migratory [4]. Species of Longidorus, Xiphinema, Trichodorus, and Paratrichodorus are also vectors of plant viruses in addition to their feeding damage [5]. Fumigants and various classes of chemical nematicides are commonly used by growers for suppressing PPN, which have potential negative impacts on the environment including the detrimental effect on beneficial soil microbiota. Due to the higher cost of fumigation and the need for effective and safe non-chemical alternatives, bionematicides are gaining interest in the recent years [6,7].

There have been reports of nematode suppressive soils where PPN populations are suppressed due to the presence of bacteria and fungi. These beneficial microorganisms limit PPN proliferation by certain trapping structures or by producing toxins. Trichoderma harzianum, Purpureocillium lilacinum, Pochonia chlamydosporia, Monacrosporium lysipagum, Pseudomonas fluorescens and Pasteuria penetrans are some of the microorganisms 
involved in nematode suppression [8-11]. Bionematicides based on the fungi P. chlamydosporia, P. lilacinum, Arthrobotrys oligospora, Trichoderma spp., and Verticillium spp., and bacteria P. fluorescens, P. penetrans, and Bacillus spp. have been used in many cropping systems including lettuce-tomato, tomato-carrot, potato, common bean, tomato, cucumber, snapdragon, wheat and sugarcane [12-19]. While these bacteria and fungi appear to be effective in PPN suppression, there is an increased interest to explore endophytes as bionematicides especially for sedentary PPN because both of them colonize the same plant tissues and the former have a better chance of suppressing the latter [20]. Since many endophytes produce secondary metabolites that have pesticidal properties, they could be excellent candidates as bionematicides [21]. This review provides an overview of bacterial and fungal endophytes as potential bionematicides, and the challenges and opportunities in associated with their commercialization.

\section{Endophytes}

Endophytes are microorganisms that colonize plant tissues and live between plant cells in a symbiotic relationship usually characterized by mutualism. Endophytes include members of bacteria, fungi, archaea, and protists, but bacteria and fungi are the most common and widely studied taxa. While the plants provide living space and nutrition to the endophytes, the latter trigger immune responses in plants that help them withstand various biotic and abiotic stresses. Since some of the endophytes are closely related to plant pathogens, but are avirulent, plants sense their presence and activate defense responses through the production of various proteins, secondary metabolites, and hormones imparting tolerance to pathogens, herbivores, and abiotic stresses such as salinity and drought. Endophytes are in rhizosphere and phylloplane and colonize plants at various stages through seeds, seedlings, or vegetative propagative materials. The species composition, population abundance, and colonization depend on the plant species and soil and environmental conditions. While the endophytism is a common phenomenon studied for a long time, the impact of endophytes on pests including PPN is a new area of scientific interest particularly due to the demand for environmentally sustainable agricultural practices. Sikora et al. [20] discussed various laboratory, greenhouse, and field studies that explored endophytes for controlling PPN.

\subsection{Fungal Endophytes}

Among other endophytes, fungal endophytes are the most common, diverse, and well-studied group for their role in imparting stress resilience to plants [22,23]. Fungal endophytes are categorized into clavicipitaceous and non-clavicipitaceous groups based on their taxonomy, evolutionary relatedness, ecology, and host range [24-27]. Calvicipitaceous endophytes include the genera Balansia, Balansiopsis, Atkinsonella, Echinodothis, Epichloe, Myriogenospora, Neotyphodium, and Parepichloe, which are commonly associated with grasses and rely on their host throughout their life cycle as mutualists $[24,26,28,29]$. These endophytes grow in the intercellular spaces of the aboveground plant tissues and are transmitted both horizontally and vertically depending on the species $[27,30]$. Nonclavicipitaceous endophytes such as Fusarium, Colletotrichum, Phomopsis, and Xylaria are found in most terrestrial plants and do not rely on plants to complete their life cycle [29,31].

Among various species, Fusarium oxysporum is the most dominant endophyte isolated from different plants and is an antagonist of fungal pathogens, insects, and PPN [32-34]. Antagonism of F. oxysporum towards Helicotylenchus multicinctus, Meloidogyne incognita, Meloidogyne graminicola, Pratylenchus goodeyi, and R. similis, in banana, melons or tomato has been reported from different studies (Table 1)[35-41]. Other examples include Epichloe coenophiala (=Acremonium coenophialum, Neotyphodium coenophialum) against Pratylenchus scribneri, Meloidogyne marylandi, and Helicotylenchus pseudorobustus in tall fescue [42-44] and Chaetomium globosum towards M. incognita in cotton [45]. 
Table 1. Effect of fungal and bacterial endophytes against plant-parasitic nematodes (PPN) in different crops.

\begin{tabular}{|c|c|c|c|c|}
\hline PPN Species & Crop & Endophytic Organism & Effect on PPN & References \\
\hline \multicolumn{5}{|l|}{ Vegetable crops } \\
\hline Meloidogyne incognita & Tomato & $\begin{array}{c}\text { Pantoe agglomerans (MK-29), } \\
\text { Cedecea davisae (MK-30), } \\
\text { Enterobacter intermedius (MK-42), } \\
\text { Pseudomonas putida (MT-19), P. } \\
\text { putida (MT-04), Pseudomonas } \\
\text { fluorescens (MK-35) }\end{array}$ & $\begin{array}{l}\text { Reduced the number of galls } \\
\text { by } 27-43 \% \text { after soil drench } \\
\text { application and reduced } \\
\text { nematode infestation as a seed } \\
\text { treatment }\end{array}$ & [46] \\
\hline M. incognita & Tomato & F. oxysporum (strain 162) & $\begin{array}{c}\text { Reduced nematode } \\
\text { penetration by } 36-56 \%\end{array}$ & [35] \\
\hline M. incognita & Tomato & $\begin{array}{c}\text { Agrobacterium radiobacter, Bacillus } \\
\text { pumilus, B. brevis, B. megaterium, B. } \\
\text { mycoides, B. licheniformis, } \\
\text { Chryseobacterium balustinum, } \\
\text { Cedecea davisae, Cytophaga } \\
\text { johnsonae, Lactobacillus paracasei, } \\
\text { Micrococcus luteus, Micrcoccus } \\
\text { halobius, Pseudomonas syringae and } \\
\text { Stenotrophomonas maltophilia. }\end{array}$ & $\begin{array}{l}\text { Reduced the number of galls } \\
\text { and egg masses by } 33 \text { and } 39 \%\end{array}$ & {$[47]$} \\
\hline M. incognita & Bhendi & $\begin{array}{c}\text { Pseudomonas spp. (EB3) } \\
\text { Bacillus spp. (EB16, EB18), } \\
\text { Methlobacterium spp. (EB19) }\end{array}$ & $\begin{array}{l}\text { Reduced the number of adult } \\
\text { females, egg masses, eggs per } \\
\text { egg mass and lowered root } \\
\text { gall index }\end{array}$ & [48] \\
\hline M. incognita & Cucumber & $\begin{array}{c}\text { Phyllosticta (Ph5110), Chaetomium } \\
\text { (Ch1001), } \\
\text { Acremonium (Ac985), Paecilomyces } \\
\text { (Pa972) }\end{array}$ & $\begin{array}{l}\text { Reduced the number of galls } \\
\text { by } 24-58 \% \text { in the first } \\
\text { screening and } 15.6-44.3 \% \text { in } \\
\text { the repeated test. Chaetomium } \\
\text { showed the highest potential } \\
\text { for seed treatment against } \\
\text { M. incognita }\end{array}$ & [49] \\
\hline M. incognita & Tomato & $\begin{array}{c}\text { Fusarium oxysporum (Fo162); } \\
\text { Rhizobium etli (G12) }\end{array}$ & $\begin{array}{l}\text { Reduced the number of eggs } \\
\text { per female } 35 \text { days after } \\
\text { nematode inoculation }\end{array}$ & {$[50]$} \\
\hline M. incognita & Tomato & $\begin{array}{c}\text { P. agglomerans (MK-29), C. davisae } \\
\text { (MK-30), Enterobacter spp. } \\
\text { (MK-42), P. putida (MT-19) }\end{array}$ & $\begin{array}{l}\text { Reduced early root penetration } \\
\text { of J2s into roots up to } 56 \% \\
\text { when applied as a root dip and } \\
\text { soil drench; Reduced the } \\
\text { number of galls by seed } \\
\text { treatment with endophytic } \\
\text { bacteria followed by soil } \\
\text { drench application }\end{array}$ & [51] \\
\hline Meloidogyne spp. & Tomato & Gliocladium spp. & $\begin{array}{l}\text { Significant decrease in damage } \\
\text { intensity to } 33 \% \text { by inoculating } \\
\text { conidial suspension at the rate } \\
\text { of } 10^{6} \mathrm{~mL}^{-1}\end{array}$ & {$[52]$} \\
\hline M. incognita & Tomato & Acremonium implicatum & $\begin{array}{l}96.0 \% \text { of J2s were killed by a } \\
\text { culture filtrate after } 48 \mathrm{~h} ; \\
\text { Formation of root galls was } \\
\text { inhibited in potted plants and } \\
\text { root gall index was reduced in } \\
\text { the field }\end{array}$ & [53] \\
\hline
\end{tabular}


Table 1. Cont.

\begin{tabular}{|c|c|c|c|c|}
\hline PPN Species & Crop & Endophytic Organism & Effect on PPN & References \\
\hline M. incognita & Tomato & $\begin{array}{l}\text { F. oxysporum; F. solani; } \\
\text { Trichoderma asperellum }\end{array}$ & $\begin{array}{c}\text { Reduced nematode } \\
\text { penetration; T. asperellum and } \\
\text { F. oxysporum isolates reduced } \\
\text { nematode egg densities by } \\
35-46 \%\end{array}$ & [36] \\
\hline M. incognita & Tomato & Bacillus cereus (BCM2) & $\begin{array}{c}\text { Reduced gall and egg mass } \\
\text { indexes }\end{array}$ & {$[54]$} \\
\hline M. incognita & Tomato & $\begin{array}{l}\text { Bacillus sp. (EB16, EB18) } \\
\text { Methylobacterium sp. (EB19) } \\
\text { Pseudomonas sp. (EB3) }\end{array}$ & $\begin{array}{l}\text { Reduced the number of adult } \\
\text { females, egg masses, eggs per } \\
\text { eggmass, soil and root } \\
\text { population of } M \text {. incognita }\end{array}$ & [55] \\
\hline \multicolumn{5}{|l|}{ Fruit crops } \\
\hline Radopholus similis & Banana & Fusarium & $\begin{array}{l}\text { Reduced the number of J2s per } \\
\text { gram root by }>80 \%\end{array}$ & {$[56]$} \\
\hline R. similis & Banana & F. oxysporum & $\begin{array}{l}\text { Reduced nematode population } \\
\text { density on tissue culture } \\
\text { plantlets by } 49-79 \%\end{array}$ & [37] \\
\hline R. similis & Banana & Fusarium spp. (V5w2) & $\begin{array}{l}\text { Decreased nematode } \\
\text { reproduction by } 22.9 \text { and } 60.6 \% \\
\text { in cultivars, Enyeru and Kibuzi } \\
\text { respectively }\end{array}$ & [57] \\
\hline
\end{tabular}

\begin{tabular}{|c|c|c|c|c|}
\hline $\begin{array}{c}\text { M. incognita, } \\
\text { Pratylenchus coffeae, } \\
\text { R. similis, } \\
\text { Helicotylenchus } \\
\text { multicinctus }\end{array}$ & Banana & $\begin{array}{c}\text { Bacillus subtilis (EPB 5, 22, } 31 \text { and } \\
\text { EPC 16) } \\
\text { Talc based }\end{array}$ & $\begin{array}{l}\text { Reduced nematode population } \\
\text { in the combined treatment of } \\
\qquad \text { EPB } 5+31\end{array}$ & [58] \\
\hline R. similis & Banana & F. oxysporum (S9, P12) & $\begin{array}{l}63 \% \text { reduction in } R \text {. similis } \\
\text { population in root system }\end{array}$ & [38] \\
\hline R. similis & Banana & F. oxysporum & $\begin{array}{l}\text { Pre-inoculation of banana } \\
\text { plantlets on one half of the root } \\
\text { system significantly reduced } \\
\text { root penetration of J2s on the } \\
\text { non-treated half of the root by } \\
\text { 30-40\% }\end{array}$ & [59] \\
\hline R. similis & Banana & F. oxysporum (V5w2) & $\begin{array}{l}\text { Disrupted nematode } \\
\text { reproduction }\end{array}$ & [60] \\
\hline R. similis & Banana & $\begin{array}{l}\text { F. oxysporum (strain } \\
\text { 162), Paecilomyces lilacinus (strain } \\
\text { 251), } \\
\text { Bacillus firmus }\end{array}$ & $\begin{array}{l}\text { Reduced nematode density by } \\
68 \% \text { after combined } \\
\text { application of F. oxysporum and } \\
\text { P. lilacinus; Application of } \\
\text { F. oxysporum and B. firmus } \\
\text { resulted in reduced J2 density } \\
\text { by } 86.2 \%\end{array}$ & [61] \\
\hline Pratylenchus goodeyi & Banana & F. oxysporum & $\begin{array}{l}\text { Increased paralysis and } \\
\text { mortality of motile stages by } \\
17-26 \% \text { and } 62-73 \% \\
\text { respectively }\end{array}$ & [39] \\
\hline M. incognita & $\begin{array}{l}\text { Squash and } \\
\text { melon }\end{array}$ & F. oxysporum (strain 162) & $\begin{array}{l}\text { Reduced early root penetration } \\
\text { of J2s in squash and melon up } \\
\text { to } 69 \text { and } 73 \% \text {, respectively }\end{array}$ & [40] \\
\hline
\end{tabular}


Table 1. Cont.

\begin{tabular}{|c|c|c|c|c|}
\hline PPN Species & Crop & Endophytic Organism & Effect on PPN & References \\
\hline $\begin{array}{l}\text { R. similis, } \\
\text { P. goodeyi, } \\
\text { H. } \text { multicinctus }\end{array}$ & Banana & F. oxysporum & $\begin{array}{l}\text { Higher nematode mortality } \\
\text { after } 24 \text { h exposure to culture } \\
\text { filtrates; } \\
\text { H. multicinctus was less } \\
\text { sensitive to culture filtrates } \\
\text { than } R \text {. similis and } P . \text { goodeyi }\end{array}$ & [41] \\
\hline P. goodeyi & Banana & F. oxysporum (4MOC321, 11SR23) & $\begin{array}{l}\text { Significant reduction of } \\
\text { P. goodeyi population by }>50 \% \\
\text { and percentage root necrosis } \\
\text { was reduced by }>30 \%\end{array}$ & [62] \\
\hline M. javanica & Banana & Streptomyces sp. & $\begin{array}{l}\text { Inhibition rate of }>50 \% \text { in vitro } \\
\text { and biocontrol efficiency of } \\
70.7 \% \text { in sterile soil against J2s }\end{array}$ & [63] \\
\hline \multicolumn{5}{|l|}{ Tuber crops } \\
\hline M. incognita & Potato & R. etli (G12) & $\begin{array}{c}\text { The no. of galls on roots was } \\
34 \% \text { lower than control }\end{array}$ & {$[64]$} \\
\hline Globodera rostochiensis & Potato & $\begin{array}{c}\text { P. fluorescens, P. putida 3, } \\
\text { P. syxantha, P. aurantiacea } 13\end{array}$ & $\begin{array}{c}\text { Reduced nematode } \\
\text { multiplication by } 40.7-42.2 \% \\
\text { over the control with } P \text {. putida } \\
3 \text { and } P \text {. aurantiacea } 13 \\
\text { respectively }\end{array}$ & {$[65]$} \\
\hline G. rostochiensis & Potato & $\begin{array}{l}\text { Bacillus carotarum, B. cereus, and } \\
\text { Pseudomonas pseudoalcaligenes }\end{array}$ & $\begin{array}{l}\text { Increased the mortality of J2s } \\
\text { by } 67-97 \% \text {; No effect on eggs; } \\
\text { suppressed the number of } \\
\text { cysts by } 51-65 \% \text { and J2s by } \\
48-76 \% \text { in greenhouse } \\
\text { experiment }\end{array}$ & {$[66]$} \\
\hline \multicolumn{5}{|l|}{ Ornamental crops } \\
\hline M. incognita & Ornamentals & $\begin{array}{l}\text { P. agglomerans (MN34); P. putida } \\
\text { 9MN12) }\end{array}$ & Decreased galling index & [67] \\
\hline \multicolumn{5}{|l|}{ Plantation crops } \\
\hline R. similis & Black pepper & $\begin{array}{l}\text { Bacillus megaterium (BP 17) and } \\
\text { Curtobacterium luteum (TC 10) }\end{array}$ & $\begin{array}{l}\text { Higher nematode suppression } \\
\text { with C. luteum followed by } \\
\text { B. megaterium }\end{array}$ & [68] \\
\hline Meloidogyne sp. & Black pepper & B. megaterium (DS9) & $\begin{array}{l}\text { Reduced nematode population } \\
\text { with great inhibition values of } \\
\qquad 81 \text { and } 73 \%\end{array}$ & [69] \\
\hline $\begin{array}{l}\text { Meloidogyne spp.; } \\
\text { Pratylenchus spp.; } \\
\text { Apratylenchus spp.; } \\
\text { Criconemella spp.; } \\
\text { Xiphinema spp.; } \\
\text { Rotylenchulus spp. }\end{array}$ & Coffee & $\begin{array}{l}\text { Bacillus spp., Serratia spp., } \\
\text { Paenibacillus spp., Enterobacter spp. } \\
\text { and Streptomyces spp. (CBG9) }\end{array}$ & $\begin{array}{l}\text { Streptomyces sp. showed } \\
\text { inhibited egg hatching by } 85 \% \\
\text { and mortality of } M \text {. incognita } \\
\text { J2s by } 85 \%\end{array}$ & [70] \\
\hline $\begin{array}{l}\text { M. incognita; } \\
\quad \text { R. similis }\end{array}$ & Black pepper & $\begin{array}{c}\text { AA2, MER7, ANIC, TT2, MER9, } \\
\text { HEN1, EH11, TT2 }\end{array}$ & $\begin{array}{l}\text { Reduced the number of root } \\
\text { galls by } 30-91 \% \text {; reduced } \\
\text { nematode population in the } \\
\text { soil by } 15-99 \%\end{array}$ & [7] \\
\hline \multicolumn{5}{|l|}{ Agricultural crops } \\
\hline M. incognita & Cotton & & $\begin{array}{l}\text { Reduced } 30-50 \% \text { of root galls } \\
\text { by seed treatment application }\end{array}$ & [71] \\
\hline
\end{tabular}


Table 1. Cont.

\begin{tabular}{|c|c|c|c|c|}
\hline PPN Species & Crop & Endophytic Organism & Effect on PPN & References \\
\hline Meloidogyne graminicola & Rice & Bacillus megaterium & $\begin{array}{c}\text { Reduced nematode } \\
\text { penetration and gall formation } \\
\text { by }>40 \%\end{array}$ & [72] \\
\hline M. graminicola & Rice & Fusarium spp. & $\begin{array}{c}\text { Reduced root-galling by } \\
29-42 \% \text { and increased root } \\
\text { weight by } 33 \%\end{array}$ & [73] \\
\hline M. incognita & Cotton & Chaetomium globosum TAMU 520 & $\begin{array}{c}\text { Inhibited nematode infection } \\
\text { and reduced female } \\
\text { production }\end{array}$ & [45] \\
\hline M. graminicola & Rice & Fusarium moniliforme Fe14 & $\begin{array}{c}\text { Reduced J2 penetration into } \\
\text { roots by } 55 \% \text { and increased } \\
\text { male to female ratio by } \\
\text { nine times. }\end{array}$ & [74] \\
\hline \multicolumn{5}{|l|}{ Fodder crops } \\
\hline Pratylenchus scribneri & Tall fescue & Epichloe coenophiala & Reduced nematode population & [42] \\
\hline Meloidogyne marylandi & Tall fescue & E. coenophiala & $\begin{array}{c}\text { Reduced the emergence of J2s, } \\
\text { number of egg masses per pot } \\
\text { and the number of eggs per } \\
\text { egg mass }\end{array}$ & {$[43,44]$} \\
\hline $\begin{array}{c}\text { P. scribneri; } \\
\text { Helicotylenchus } \\
\text { pseudorobustus; } M . \\
\text { marylandi }\end{array}$ & Tall fescue & E. coenophiala & $\begin{array}{l}\text { Hinderance in reproduction of } \\
\text { the nematodes }\end{array}$ & [43] \\
\hline Pratylenchus spp. & Tall fescue & E. coenophiala & $\begin{array}{l}\text { Non-ergot strain AR584 confer } \\
\text { resistance in cv. Georgia } 5\end{array}$ & [75] \\
\hline $\begin{array}{l}\text { Tylenchorhynchus spp., } \\
\text { Criconemella spp., } \\
\text { Helicotylenchus spp.; } \\
\text { Pratylenchus spp. }\end{array}$ & Tall fescue & $\begin{array}{c}\text { E. coenophiala (AR584; AR542; } \\
\text { AR502) }\end{array}$ & $\begin{array}{l}\text { No effect on nematode } \\
\text { population densities }\end{array}$ & [76] \\
\hline \multicolumn{5}{|l|}{ Forest trees } \\
\hline $\begin{array}{l}\text { Bursaphelenchus } \\
\quad \text { xylophilus }\end{array}$ & Pine trees & $\begin{array}{l}\text { Escherichia coli (M131, M132) } \\
\text { Serratia marcescens (M44) }\end{array}$ & $\begin{array}{c}\text { E. coli and } S . \text { marcescens } \\
\text { showed significant nematicidal } \\
\text { activity (67 and } 60 \% \text { mortality) } \\
\text { respectively }\end{array}$ & [77] \\
\hline M. incognita & $\begin{array}{c}\text { Shorea sp.; } \\
\text { Swietenia sp.; } \\
\text { Albizia falcataria; } \\
\text { Anthocephalus } \\
\text { cadamba; } \\
\text { Juglans nigra }\end{array}$ & Bacterial isolates & $\begin{array}{l}\text { Inhibited egg hatching up to } \\
81 \% \text { and mortality up to } 85 \%\end{array}$ & [78] \\
\hline B. xylophilus & Pine trees & Stenotrophomonas and Bacillus sp. & $\begin{array}{l}\text { Significant inhibitory activity } \\
\text { against PWN during their } \\
\text { developmental stages }\end{array}$ & [79] \\
\hline
\end{tabular}

\subsection{Bacterial Endophytes}

Bacterial endophytes are the second most common endophytes and colonize most plant species locally or systemically living within the cells, in the intercellular spaces or vascular system $[71,80]$. Their antagonism towards PPN has been reported since mid1990s [71,81]. Most of the Gram-negative endophytes and some species of Gram-positive endophytes are antagonists of plant pathogens [82]. Agrobacterium radiobacter, Burkholderia cepacian, and P. fluorescens are examples of Gram-negative endophytes and Bacillus spp. 
are examples of Gram-positive endophytes. It has also been found that species of Acrhomobacter, Acinetobacter, Agrobacterium, Bacillus, Brevibacterium, Microbacterium, Pseudomonas, Xanthomonas, and others have the potential for controlling PPN [83].

\subsection{Mode of Action of Endophytes}

Endophytes suppress the growth and development of various stages of PPN through various mechanisms and thus contribute to the improvement of plant health. These can be categorized into direct and indirect mechanisms as described below:

\subsubsection{Direct Mechanisms}

Endophytes can directly attack, kill, immobilize or repel PPN as they find their host, compete for space and produce secondary metabolites and other compounds that are detrimental to PPN. Endophytes produce metabolites such as flavonoids, peptides, quinones, alkaloids, steroids, phenols, terpenoids, and polyketones or lytic enzymes such as chitinases, cellulases, hemicellulases, and 1,3-glucanases [84-86]. These compounds inhibit the growth and development of PPN and other biotic stressors through antibiosis. Additionally, endophytes occupy plant tissues and inhibit PPN through niche competition or competitive displacement [85]. For example, F. oxysporum isolated from banana, paralyzes and kills P. goodeyi [39], while C. globosum produce secondary metabolites viz., chaetoglobosin A, chaetoglobosin B, flavipin, 3-methoxyepicoccone and 4,5,6-trihydroxy-7-methylphthalide against $M$. incognita [87].

\subsubsection{Indirect Mechanisms}

Endophytes induce systemic resistance by upregulating genes that produce various phytohormones, phytoalexins, volatile organic compounds, pathogenesis-related proteins, and trigger salicylic acid, jasmonic acid, and ethylene pathways that protect plants from stressors. Some of these defenses antagonize stressors such as PPN while others such as phytohormones promote plant growth and compensate for the damage by stressors. Additionally, endophytes can also influence root exudate composition and production that further inhibit stressors. For example, Bacillus sphaericus B43 and Rhizobium etli G12 application induced systemic resistance to Globodera pallida in potato [88] and to M. incognita in tomato [89]. Meloidogyne incognita showed a preference to root exudates extracted from tomato roots than those extracted from roots colonized by endophytic F. oxysporum strain Fo162 [35]. Such an interaction was also observed in M. graminicola with respect to rice in the presence or absence of F. moniliforme strain Fe14 [74].

\section{Endophytes as Bionematicides}

While regulatory guidelines might place certain endophytes as biostimulants or soil amendments and others as biopesticides, for this review, we present various examples of endophytes as microbial control agents of PPN in a variety of crops and forestry.

\subsection{Vegetable Crops}

Researchers around the world evaluated the culture filtrates of bacterial and fungal endophytes against root-knot nematodes in cucumber, okra, and tomato with a majority of the studies in tomato (Table 1) [35,46,47,50-55]. Tian et al. [53] reported that Acremonium implicatum inhibited the formation of root galls caused by $M$. incognita in potted tomato plants to 41 per plant compared to 122 in untreated plants. Under field conditions, root gall index was significantly reduced to 25 from the endophyte treatment compared to 96 in untreated plants. In a greenhouse study, Hu et al. [54] found that various isolates of Bacillus cereus caused 53-76\% reduction in M. incognita egg masses, $70-81 \%$ reduction in gall formation while repelling second stage juveniles (J2s). Similarly, isolates of Bacillus sp., Methylobacterium sp., and Pseudomonas sp. significantly reduced the egg masses, number of eggs per egg mass, number of adult females, and overall $M$. incognita numbers in both soil and roots of tomato growing in pots [55]. The two isolates of Bacillus sp. resulted in the 
lowest gall index of 1.33 compared to 4.67 in control plants. Zhao et al. [90] reported $88-93 \%$ mortality in M. incognita J2s and 88-83\% reduction in egg-hatch from Pseudomonas protegens and Serratia plymuthica in greenhouse tomato. Metabolites of both bacteria reduced the number of egg masses and root galls, while $P$. protegens also promoted seed germination and plant growth. In another study, Munif et al. [78] obtained $81 \%$ mortality of J2s and $81 \%$ reduction in egg-hatch of $M$. incognita with a consortium of bacterial endophytes isolated from trees. Details of these endophytic species were not revealed, however.

Seed treatment with endophytes has been explored as an option for controlling PPN. Yan et al. [49] found that Acremonium sp., Chaetomium sp., Fusarium spp., Paecilomyces sp., Phyllosticta sp., and Trichoderma sp. reduced the number of galls by M. incognita in cucumber after treating the seeds. Metabolites from some of these endophytes negatively impacted the motility of J2s. Among these fungi, Chaetomium sp. had the highest colonization of roots $(70.5 \%)$ and aboveground parts (73.5\%) with $42-47 \%$ reduction in root galls. In another study, bacterial isolates of Pantoe aagglomerans, Cedecea davisae, Enterobacter spp., and Pseudomonas putida reduced early root penetration of $M$. incognita in tomato by up to $56 \%$ when applied as seed treatment, root dip, or soil drench [51]. Seed treatment followed by soil drenching appeared to be more effective than single application in reducing gall formation.

Some consider that a consortium of beneficial microorganisms is better than using a single microorganism and several commercial products based on microbial consortia have been developed in the recent years [78,91]. However, consortia may not always provide better control than a single endophyte due to potential negative interactions among the members. For example, the fungal endopyte Piriformospora indica alone suppressed M. incognita infestations in tomato better than as a member of a consortium with Bacillus pumilus and P. fluorescens [92]. While all of them promoted the plant growth, nematode control of $P$. indica decreased in the presence of bacterial endophytes.

\subsection{Fruit Crops}

In pineapple, application of Bacillus sp. isolated from its roots suppressed R. reniformis infestations by $54-60 \%$ in two cultivars [93]. Crop rotation with sunn hemp (Crotalaria juncea) and application of the endophyte were found to be effective non-chemical alternatives for PPN control in pineapple. Effective use of F. oxysporum for controlling PPN in banana has been reported from several studies. Fusarium isolates induced systemic resistance and caused up to $41 \%$ of reduction in $R$. similis $\mathrm{J} 2 \mathrm{~s}$ penetration 15 days after treatment in a greenhouse study [59]. Three strains of F. oxysporum caused $>85 \%$ mortality of $R$. similis, $P$. goodeyi and H. multicinctus mixed stages (J2s, males and females) after $24 \mathrm{~h}$ of exposure [41]. A strain of Streptomyces sp. isolated from banana roots showed $>50 \%$ inhibiting rate of Meloidogyne javanica J2s in vitro and 71\% of biocontrol efficiency in sterile soil [63]. However, in the presence of Streprtomyces sp., populations of bacterivorous nematode genera Mesorhabditis and Cephalobus also increased. In another study, Mendoza and Sikora [61] found that the combination of the strains of F. oxysporum and the egg parasitic fungus P. lilacinum (=Paecilomyces lilacinus) reduced $R$. similis populations by $68.5 \%$ while the combination of F. oxysporum and Bacillus firmus reduced PPN populations by $86 \%$ in banana under greenhouse conditions.

\subsection{Tuber Crops}

In potato, A. radiobacter and B. sphaericus induced systemic resistance against the potato cyst nematode, G. pallida [94]. Another study demonstrated significant control of M. incognita in potato from R. etli G12 application with 34\% fewer galls than in control [64]. Bacillus carotarum, B. cereus, and Pseudomonas pseudoalcaligenes isolated from the roots and tubers of potato caused $\geq 80 \%$ mortality of Globodera rostochiensis J2s in vitro but did not limit the egg-hatch [66]. 


\subsection{Ornamental Crops}

There was only one example of using endophytes for PPN control in ornamental crops. Application of the endophytic bacteria P. agglomerans (MN34) and P. putida (MN12) reduced the gall index from M. incognita and promoted plant growth in natal plum (Carissa macrocarpa), dwarf lilyturf (Ophopogan japonicas), and other ornamental plants [67].

\subsection{Plantation Crops}

Endophytes for PPN control have been explored in black pepper, coffee, and other crops. In an Indian study, B. megaterium and Curtobacterium leteum, isolated from black pepper, provided the highest suppression of $R$. similis J2s among other isolates tested [68]. Similarly, a Vietnamese isolate of B. megaterium reduced numbers of Meloidogyne sp. by 82 and $73 \%$ in soil and pepper roots, respectively [69]. In Indonesia, 52\% suppression in root galls and $75 \%$ suppression in $M$. incognita numbers was observed from the application of endophytic bacteria isolated from pepper plants [7]. When organic matter, in the form of cow manure, was applied along with endophytic bacteria, there was a 93\% decrease in root galls and $97 \%$ decrease in nematode populations while a commercial organic fertilizer applied with endophytes caused 86 and $79 \%$ reduction in root galls and nematode numbers, respectively. In Vietnam, Streptomyces sp. (CBG9) isolated from robusta coffee in Central Highland inhibited M. incognita egg-hatch by $86 \%$ and caused $85 \%$ of mortality in J2s [70].

\subsection{Agricultural Crops}

Meloidogyne graminicola is an important pest of rice in South Asia and South East Asia. Rice is a staple food of billions around the world and M. graminicola is one of the pests that cause significant losses, if left uncontrolled. Various studies demonstrated the potential of endophytes in controlling M. graminicola. In Taiwan, B. megaterium, isolated from rice growing regions, provided more than $40 \%$ reduction in J2 penetration and gall formation by M. graminicola and 60\% reduction of J2 migration [72]. In a German study, Fusarium isolates from rice producing areas in Vietnam reduced gall formation by $29-42 \%$ and improved the root weight by $33 \%$ [73]. Trichoderma spp. evaluated in this study also had a similar impact with up to $38 \%$ reduction in root galling. Similarly, in another German study F. moniliforme ( $\mathrm{Fe} 14$ ) suppressed J2s penetration by $55 \%$ and increased the male to female ratio by 9 times [74]. Additionally, root exudates from endophyte treated plants were also less attractive to J2s.

In the US, C. globosum (TAMU 520), isolated from upland cotton used as a seed treatment, negatively impacted M. incognita, the cotton aphid (Aphis gossypii), and the beet armyworm (Spodoptera exigua) [45]. Endophyte reduced nematode infection and female reproduction as well as the fecundity of both insect species. In a different study in the USA, hundreds of nematophagous fungal endophytes were isolated from the roots of corn and soybean where the majority was Fusarium spp. along with less common Hirsutella rhossiliensis, Metacordyceps chlamydosporia, and Arthrobotrys iridis [95]. It was also observed that PPN population density influences the endophyte diversity as the fungal diversity in soybean roots was higher when Heterodera glycines density was higher.

\subsection{Fodder Crops}

Species of Epichlö (=Neotyphoidium and Acremonium) are endophytes of Gramineae family that contains tall fescue, perennial rye grass and others used for fodder. Although some endophytes release metabolites that are toxic to cattle, there are several examples of PPN reduction from the presence of various species of endophytes (Table 1). An earlier report indicated that the presence of the fungal endophyte E. coenophiala significantly reduced populations of P. scribneri and Tylenchorhynchus acutus in tall fescue and improved the yields [42]. However, endophyte colonized grass appeared to be toxic to cattle because of the ergot alkaloids they release. Inoculating tall fescue with non-ergotic strain of E. coenophiala offered resistance to Pratylenchus zeae and P. scribneri, however, to a lesser extent than ergotic strains [75]. In another study, $100 \%$ mortality of M. marylandi was 
observed when PPN-infested soil in pots was inoculated with E. coenophiala and with water deficit stress [44].

\subsection{Forestry}

The pine wilt nematode, Bursaphelenchus xylophilus, is a serious problem in Korea, Canada, USA, China, Japan and other South Eastern countries causing pine wilt of coniferous trees of the genus Pinus. Ponpandian et al. [79] isolated and investigated hundreds of bacterial endophytes for controlling B.xylophilus. Among them, Stenotrophomonas spp. and Bacillus spp. were very effective, causing $\geq 70 \%$ mortality of adult nematodes. Liu et al. [77] isolated 48 genera of Gamma-proteobacteria and others from four species of pine trees in Korea. Among those isolates, Escherichia coli and Serratia marcescens produced nematicidal metabolites causing 67 and 60\% mortality in B. xylophilus, respectively, in laboratory assays.

\section{Metabolites from Endophytes}

Endophytes produce an array of secondary metabolites, which have biopesticide potential against plant pathogens and PPN. These metabolites categories include alkaloids, flavonoids, peptides, phenols, polyketones, quinols, terpenoids, and steroids [96], which induce systemic resistance in plants against various biotic and abiotic stresses.Several of these secondary metabolites have nematicidal properties and can be important IPM options (Table 2). For example, F. oxysporum isolated from the roots of the tomato cultivar Moneymaker produces several bioactive compounds including 4-hydroxybenzoic acid, indole-3-acetic acid, and gibepyrone $\mathrm{D}$, which are nematicidal with $\mathrm{LC}_{50}$ values of 104,117 , and $134 \mu \mathrm{g} / \mathrm{mL}$, respectively [97]. In another study, five metabolites - chaetoglobosin A, chaetoglobosin B, flavipin, 3-methoxyepicoccone, and 4, 5, 6-trihydroxy-7-methylphthalide-derived from C. globosum caused moderate to high levels of mortality in $M$. javanica J2s [87]. With $\mathrm{LC}_{50}$ values of $200 \mu \mathrm{g} / \mathrm{mL}$, chaetoglobosin A and B significantly suppressed nematode reproduction and promoted plant growth in a potted plant study.

Table 2. Secondary metabolites identified in endophytes and their effect on PPN.

\begin{tabular}{|c|c|c|c|}
\hline Metabolite & Bacteria/Fungi & Nematode & References \\
\hline Pregaliellalactone & Galiella rufa & Meloidogyne incognita & [98] \\
\hline 3-Hydroxypropionic acid & Endophytic fungi & M. incognita & [99] \\
\hline $\begin{array}{l}\text { Chlorinated oxazinane derivate }\left(1-\left[\left(2 R^{*}, 4 S^{*}, 5 S^{*}\right) \text { - }\right.\right. \\
\text { 2-chloro-4-methyl-1,3-oxazinan-5-yl] ethenone }) \\
\text { and an epimer of the former }\left(1-\left[\left(2 R^{*}, 4 S^{*}, 5 R^{*}\right)-2 \text { - }\right.\right. \\
\text { chloro-4-methyl-1,3-oxazinan-5-yl] } \\
\text { ethanone })\end{array}$ & Geotrichum sp. (AL4) & $\begin{array}{l}\text { Bursaphelenchus xylophilus; } \\
\text { Panagrellus redivious }\end{array}$ & [100] \\
\hline Fusaric acid and Bikaverin & Fusarium oxysporum (EF119) & B. xylophilus & [101] \\
\hline (R)-(-)-2-ethylhexan-1-ol & $\begin{array}{l}\text { Brevundimonas diminuta } \\
\text { (LCB-3) }\end{array}$ & B. xylophilus & [102] \\
\hline Chaetoglobosin A & Chaetomium globosum (NK102) & M. incognita & [103] \\
\hline $\begin{array}{l}\text { 3-methyl-1-butanol, }( \pm) \text {-2-methyl-1-butanol, } \\
\text { 4-heptanone, and isoamyl acetate }\end{array}$ & Daldinia cf. concentrica & Meloidogyne javanica & [104] \\
\hline $\begin{array}{l}\text { 4-hydroxybenzoic acid, indole- } \\
\text { 3-acetic acid and gibepyrone D }\end{array}$ & F. oxysporum (162) & M. incognita & [97] \\
\hline Chaetoglobosin A, chaetoglobosin B and flavipin & C. globosum (YSC5) & M. javanica & [87] \\
\hline
\end{tabular}

\section{Commercialization}

Identification, mass-production, and commercialization of nematicidal endophytes have a great potential for PPN control in many systems in a sustainable manner. Since some of these endophytes induce systemic resistance against multiple stressors or antagonize multiple categories of pests, endophytes can be comprehensive tools for improving 
overall crop health, yields, and optimize the cost of crop care. Although numerous studies demonstrated the potential of bacterial and fungal endophytes for controlling PPN, there are noncommercial nematicides based on these endophytes. However, some strains are available as biostimulants or biofungicides.

\section{Constraints and Future Opportunities}

Major constraints of biopesticides are their high cost of production and relatively fewer efficacy data compared to synthetic pesticides. As a result, there is some hesitation in the farming community to use biopesticides as their primary choice. Some of the reasons for low, slow, or inconsistent field performance of some endophytes are adverse soil conditions, competition with other soil microorganisms, the presence of mycophagous or bacteriophagous nematodes $[105,106]$. In some cases, endophytes might release toxic metabolites that are harmful to herbivorous mammals or alter the microbial community in the rhizosphere or phylloplane with negative consequences [107].

Some strategies to improve the prospects of bionematicides based on endophytic bacteria and fungi are investing in applied research that generates field efficacy data, developing formulation technologies that optimize production costs and improve product efficacy, and educating the farming community with IPM practices that make the best use of bionematicides and other such products. Research, outreach, communication at various levels, employing various control options, and exploiting modern technologies for monitoring crop health and delivering agricultural inputs are various elements of IPM [108]. When bionematicides are integrated with other management practices, they provide effective and long-term suppression of PPN.

Author Contributions: Conceptualization, K.K.K. and S.K.D.; methodology, K.K.K. and S.K.D.; writing-original draft preparation, K.K.K. and S.K.D.; writing-review and editing, S.K.D. All authors have read and agreed to the published version of the manuscript.

Funding: This research received no external funding.

Institutional Review Board Statement: Not applicable.

Informed Consent Statement: Not applicable.

Data Availability Statement: Not applicable.

Conflicts of Interest: The authors declare no conflict of interest.

\section{References}

1. Palomares-Rius, J.E.; Escobar, C.; Cabrera, J.; Vovlas, A.; Castillo, P. Anatomical alterations in plant tissues induced by plantparasitic nematodes. Front. Plant Sci. 2017, 8, 1987. [CrossRef] [PubMed]

2. Caboni, P.; Aissani, N.; Demurtas, M.; Ntalli, N.; Onnis, V. Nematicidal activity of acetophenones and chalcones against Meloidogyne incognita, and structure-activity considerations. Pest Manag. Sci. 2016, 72, 125-130. [CrossRef]

3. Abd-Elgawad, M.M.M.; Askary, T.H. Impact of phytonematodes on agriculture economy. In Biocontrol Agents of Phytonematodes; Askary, T.H., Martinelli, P.R.P., Eds.; CAB International: Wallingford, UK, 2015; pp. 3-49.

4. Jones, J.T.; Haegeman, A.; Danchin, E.G.; Gaur, H.S.; Helder, J.; Jones, M.G.; Kikuchi, T.; Manzanilla-López, R.; Palomares-Rius, J.E.; Wesemael, W.M.; et al. Top 10 plant-parasitic nematodes in molecular plant pathology. Mol. Plant Pathol. $2013,14,946-961$. [CrossRef]

5. Dijkstra, J.; de Jager, C.P. Virus transmission by nematodes. In Practical Plant Virology: Protocols and Excercises; Dijkstra, J., de Jager, C.P., Eds.; Springer: Berlin, Germany, 1998; pp. 128-142.

6. Kumar, K.K.; Sridhar, J.; Murali-Baskaran, R.K.; Senthil-Nathan, S.; Kaushal, P.; Dara, S.K.; Arthurs, S. Microbial biopesticides for insect pest management in India: Current status and future prospects. J. Invertebr. Pathol. 2019, 165, 74-81. [CrossRef]

7. Munif, A.; Harni, R. Management of endophytic bacteria and organic material for the biological control of yellowing disease on pepper. IOP Conf. Ser. Earth Environ. Sci. 2020, 418, 012052. [CrossRef]

8. Davies, K.G.; Srivastava, A.; Kumar, K.K.; Mohan, S. Understanding nematode suppressive soils: Molecular interactions between Pasteuria endospores and the nematode surface coat. In Proceedings of the 4th Symposium of Potato Cyst Nematode Management (including Other Nematode Parasites of Potatoes), Newport, UK, 7-8 September 2015; Association of Applied Biologists: Wellesbourne, UK, 2015. 
9. Li, J.; Zou, C.; Xu, J.; Ji, X.; Niu, X.; Yang, J.; Huang, X.; Zhang, K.-Q. Molecular mechanisms of nematode-nematophagous microbe interactions: Basis for biological control of plant-parasitic nematodes. Annu. Rev. Phytopathol. 2015, 53, 67-95. [CrossRef] [PubMed]

10. Silva, J.C.P.D.; Medeiros, F.H.V.; Campos, V.P. Building soil suppressiveness against plant-parasitic nematodes. Biocontrol Sci. Technol. 2018. [CrossRef]

11. Topalovi 'c, O.; Hussain, M.; Heuer, H. Plants and associated soil microbiota cooperatively suppress plant-parasitic nematodes. Front. Microbiol. 2020, 11, 313. [CrossRef] [PubMed]

12. Verdejo-Lucas, S.; Sorribas, F.J.; Ornat, C.; Galeano, M. Evaluating Pochonia chlamydosporia in a double-cropping system of lettuce and tomato in plastic houses infested with Meloidogyne javanica. Plant Pathol. 2003, 52, 521-528. [CrossRef]

13. Affokpon, A.; Coyne, D.L.; Htay, C.C.; Agbèdè, R.D.; Lawouin, L.; Coosemans, J. Biocontrol potential of native Trichoderma isolates against root-knot nematodes in West African vegetable production systems. Soil Biol. Biochem. 2011, 43, 600-608. [CrossRef]

14. Sellitto, V.M.; Curto, G.; Dallavalle, E.; Ciancio, A.; Colagiero, M.; Pietrantonio, L.; Bireescu, G.; Stoleru, V.; Storari, M. Effect of Pochonia chlamydosporia-based formulates on the regulation of root-knot nematodes and plant growth response. Front. Life Sci. 2016, 9, 177-181. [CrossRef]

15. Wepuhkhulu, M.; Kimenju, J.; Anyango, B.; Wachira, P.; Kyallo, G. Effect of soil fertility management practices and Bacillus subtilis on plant parasitic nematodes associated with common bean, Phaseolus vulgaris. Trop. Subtrop. Agroecosyst. 2011, 13, 27-34.

16. Kokalis-Burelle, N. Pasteuria penetrans for control of Meloidogyne incognita on tomato and cucumber, and M. arenaria on snapdragon. J. Nematol. 2015, 47, 207. [PubMed]

17. Zhao, D.; Zhao, H.; Zhao, D.; Zhu, X.; Wang, Y.; Duan, Y.; Xuan, Y.; Chen, L. Isolation and identification of bacteria from rhizosphere soil and their effect on plant growth promotion and root-knot nematode disease. Biol. Control 2018, 119, 12-19. [CrossRef]

18. Zhang, S.W.; Gan, Y.T.; Xu, B.L.; Xue, Y.Y. The parasitic and lethal effects of Trichoderma longibrachiatum against Heterodera avenae. Biol. Control 2014, 72, 1-8. [CrossRef]

19. Mazzuchelli, R.D.C.L.; Mazzuchelli, E.H.L.; de Araujo, F.F. Efficiency of Bacillus subtilis for root-knot and lesion nematodes management in sugarcane. Biol. Control 2020, 143, 104185. [CrossRef]

20. Sikora, R.A.; Schafer, K.; Dababat, A.A. Modes of action associated with microbially induced in planta suppression of plantparasitic nematodes. Aust. Plant Pathol. 2007, 36, 124-134. [CrossRef]

21. Yadav, A.N. Endophytic fungi for plant growth promotion and adaptation under abiotic stress conditions. Acta Sci. Agric. 2019, 3, 91-93.

22. Lugtenberg, B.J.; Caradus, J.R.; Johnson, L.J. Fungal endophytes for sustainable crop production. FEMS Microbiol. Ecol. 2016, 92, fiw194. [CrossRef]

23. Yan, L.; Zhu, J.; Zhao, X.; Shi, J.; Jiang, C.; Shao, D. Beneficial effects of endophytic fungi colonization on plants. Appl. Microbiol. Biotechnol. 2019, 103, 3327-3340. [CrossRef]

24. Rodriguez, R.J.; White, J.F., Jr.; Arnold, A.E.; Redman, R.S. Fungal endophytes: Diversity and functional roles. New Phytol. 2009, 182, 314-330. [CrossRef]

25. Kusari, S.; Hertweck, C.; Spiteller, M. Chemical ecology of endophytic fungi: Origins of secondary metabolites. Chem. Biol. 2012, 19, 792-798. [CrossRef] [PubMed]

26. O'Hanlon, K.A.; Knorr, K.; Jorgensen, L.N.; Nicolaisen, M.; Boelt, B. Exploring the potential of symbiotic fungal endophytes in cereal disease suppression. Biol. Control 2012, 63, 69-78. [CrossRef]

27. Santangelo, J.S.; Turley, N.E.; Johnson, M.T. Fungal endophytes of Festuca rubra increase in frequency following long term exclusion of rabbits. Botany 2015, 93, 233-241. [CrossRef]

28. Hardoim, P.R.; van Overbeek, L.S.; Berg, G.; Pirttilä, A.M.; Compant, S.; Campisano, A.; Döring, M.; Sessitsche, A. The hidden world within plants: Ecological and evolutionary considerations for defining functioning of microbial endophytes. Microbiol. Mol. Biol. Rev. 2015, 79, 293-320. [CrossRef]

29. De Silva, N.I.; Lumyong, S.; Hyde, K.D.; Bulgakov, T.; Phillips, A.J.L.; Yan, J.Y. Mycosphere essays 9: Defining biotrophs and hemibiotrophs. Mycosphere 2016, 7, 545-559. [CrossRef]

30. Schardl, C.L.; Leuchtmann, A.; Spiering, M.J. Symbioses of grasses with seed borne fungal endophytes. Annu. Rev. Plant Biol. 2004, 55, 315-340. [CrossRef] [PubMed]

31. Jayawardena, R.S.; Hyde, K.D.; Damm, U.; Cai, L.; Liu, M.; Li, X.H.; Zhang, W.; Zhao, W.S.; Yan., J.Y. Notes on currently accepted species of Colletotrichum. Mycosphere 2016, 7, 1192-1260. [CrossRef]

32. Alabouvette, C.; Couteaudier, Y. Biological control of Fusarium wilts with nonpathogenic Fusaria. In Biological Control of Plant Diseases. NATO ASI Series (Series A: Life Sciences); Tjamos, E.C., Papavizas, G.C., Cook, R.J., Eds.; Springer: Boston, MA, USA, 1992; pp. 415-426.

33. Hallmann, J.; Sikora, R.A. Influence of F. oxysporum, a mutualistic fungal endophyte, on M. incognita of tomato. J. Plant Dis. Protect. 1994, 101, 475-481.

34. Griesbach, M. Occurrence of Mututalistic Fungal Endophytes in Bananas (Musa spp.) and Their Potential as Biocontrol Agents of Banana Weevil (Germar) in Uganda. Ph.D. Thesis, University of Bonn, Bonn, Germany, 1999.

35. Dababat, A.E.F.A.; Sikora, R.A. Influence of the mutualistic endophyte Fusarium oxysporum 162 on Meloidogyne incognita attraction and invasion. Nematology 2007, 9, 771-776. 
36. Bogner, C.W.; Kariuki, G.M.; Elashry, A.; Sichtermann, G.; Buch, A.K.; Mishra, B.; Thines, M.; Grundler, F.M.W.; Schouten, A. Fungal root endophytes of tomato from Kenya and their nematode biocontrol potential. Mycol. Progress 2016, 15, 30. [CrossRef]

37. Niere, B.I. Significance of Non-Pathogenic Isolates of Fusarium oxysporum Schlecht: Fries for the Biological Control of the Burrowing Nematode Radopholus similis (Cobb) Thorne on Tissue Cultured Banana. Ph.D. Thesis, University of Bonn, Bonn, Germany, 2001.

38. Felde, A.Z.; Pocasangre, L.E.; Carnizares Monteros, C.A.; Sikora, R.A.; Rosales, F.E.; Riveros, A.S. Effect of combined inoculations of endophytic fungi on the biocontrol of Radopholus similis. InfoMusa 2006, 15, 12-18.

39. Mwaura, P.; Dubois, T.; Losenge, T.; Coyne, D.; Kahangi, E. Effect of endophytic Fusarium oxysporum on paralysis and mortality of Pratylenchus goodeyi. Afr. J. Biotechnol. 2010, 9, 1130-1134.

40. Menjivar, R.D.; Hagemann, M.H.; Kranz, J.; Cabrera, J.A.; Dababat, A.A.; Sikora, R.A. Biological control of Meloidogyne incognita on cucurbitaceous crops by the non-pathogenic endophytic fungus Fusarium oxysporum strain 162. Int. J. Pest Manag. 2011, 57, 249-253. [CrossRef]

41. Van Dessel, P.; Coyne, D.; Dubois, T.; Waele, D.D.; Franco, J. In vitro nematicidal effect of endophytic Fusarium oxysporum against Radopholus similis, Pratylenchus goodeyi and Helicotylenchus multicinctus. Nematropica 2011, 41, 154-160.

42. West, C.P.; Izekor, E.; Oosterhuis, D.M.; Robbins., R.T. The effect of Acremonium coenophialum on the growth and nematode infestation of tall fescue. Plant Soil 1988, 112, 3-6. [CrossRef]

43. Kimmons, C.A.; Quinn, K.D.; Bernard, E.C. Nematode reproduction on endophyte infected and endophyte-free tall rescue. Plant Dis. 1990, 74, 757-761. [CrossRef]

44. Elmi, A.A.; West, C.P.; Robbins, R.T.; Kirkpatrick, T.L. Endophyte effects on reproduction of a root-knot nematode (Meloidogyne marylandi) and osmotic adjustment in tall fescue. Grass Forage Sci. 2000, 55, 166-172. [CrossRef]

45. Zhou, W.; Starr, J.L.; Krumm, J.L.; Sword, G.A. The fungal endophyte Chaetomium globosum negatively affects both above-and belowground herbivores in cotton. FEMS Microbiol. Ecol. 2016, 92, fiw158. [CrossRef]

46. Munif, A.; Hallmann, J.; Sikora, R.A. Evaluation of the biocontrol activity of endophytic bacteria from tomato against Meloidogyne incognita. Meded. Fac. Landbouwkund. EnToegepaste Biol. Wet. Univ. Gent. 2000, 65, 471-480.

47. Mekete, T.; Hallmann, J.; Kiewnick, S.; Sikora, R. Endophytic bacteria from Ethiopian coffee plants and their potential to antagonize Meloidogyne incognita. Nematology 2009, 11, 117-127.

48. Vetrivelkalai, P.; Sivakumar, M.; Jonathan, E.I. Biocontrol potential of endophytic bacteria on Meloidogyne incognita and its effect on plant growth in bhendi. J. Biopestic. 2010, 3, 452-457.

49. Yan, X.-N.; Sikora, R.A.; Zheng, J.-W. Potential use of cucumber (Cucumis sativus L.) endophytic fungi as seed treatment agents against root-knot nematode Meloidogyne incognita. J. Zhejiang Univ.-Sci. B (Biomed. Biotechnol.) 2011, 12, 219-225. [CrossRef] [PubMed]

50. Martinuz, A.; Schouten, A.; Sikora, R.A. Post-infection development of Meloidogyne incognita on tomato treated with the endophytes Fusarium oxysporum strain Fo162 and Rhizobium etli strain G12. BioControl 2013, 58, 95-104. [CrossRef]

51. Munif, A.; Hallmann, J.; Sikora, R.A. The influence of endophytic bacteria on Meloidogyne incognita infection and tomato plant growth. J. ISSAAS 2013, 19, 68-74.

52. Amin, N. The use of fungal endophytes Gliocladium spp. in different concentration to control of root-knot nematode Meloidogyne spp. Acad. Res. Int. 2014, 5, 91-95.

53. Tian, X.; Yao, Y.; Chen, G.; Mao, Z.; Wang, X.; Xie, B. Suppression of Meloidogyne incognita by the endophytic fungus Acremonium implicatum from tomato root galls. Int. J. Pest Manag. 2014, 60, 239-245. [CrossRef]

54. Hu, H.; Chen, Y.; Wang, Y.; Tang, Y.; Chen, S.; and Yan, S. Endophytic Bacillus cereus effectively controls Meloidogyne incognita on tomato plants through rapid rhizosphere occupation and repellent action. Plant Dis. 2017, 101, 448-455. [CrossRef]

55. Vetrivelkalai, P. Evaluation of endophytic bacterial isolates against root knot nematode, Meloidogyne incognita in tomato under glasshouse condition. Int. J. Curr. Microbiol. App. Sci. 2019, 8, 2584-2589. [CrossRef]

56. Pocasangre, L. Biological Enhancement of Banana Tissue Culture Plantlets with Endophytic Fungi for the Control of the Burrowing Nematode Radopholus similis and the Panama Disease (Fusarium oxysporum f. sp. cubense). Ph.D. Thesis, University of Bonn, Bonn, Germany, 2000.

57. Dubois, T.; Gold, C.S.; Coyne, D.; Paparu, P.; Mukwaba, E.; Athman, S.; Kapindu, S.; Adipala, E. Merging biotechnology with biological control: Banana Musa tissue culture plants enhanced by endophytic fungi. Uganda J. Agric. Sci. 2004, 9, 445-451.

58. Jonathan, E.I.; Umamaheswari, R. Biomanagement of nematodes infesting banana by bacterial endophytes (Bacillus subtilis). Indian J. Nematol. 2006, 36, 6303-6960.

59. Vu, T.; Sikora, R.; Hauschild, R. Fusarium oxysporum endophytes induced systemic resistance against Radopholus similis on banana. Nematology 2006, 8, 847-852. [CrossRef]

60. Viljoen, A.; Labuschagne, N.; Dubois, T.; Athman, S.; Coyne, D.; Gold, C.S. Effect of endophytic Fusarium oxysporum on root penetration and reproduction of Radopholus similis in tissue culture-derived banana (Musa spp.) plants. Nematology 2007, 9, 599-607. [CrossRef]

61. Mendoza, A.R.; Sikora, R.A. Biological control of Radopholus similis in banana by combined application of the mutualistic endophyte Fusarium oxysporum strain 162, the egg pathogen Paecilomyces lilacinus strain 251 and the antagonistic bacteria Bacillus firmus. Biocontrol 2009, 54, 263-272. [CrossRef] 
62. Waweru, B.W.; Losenge, T.; Kahangi, E.M.; Dubois, T.; Coyne, D. Potential biological control of lesion nematodes on banana using Kenyan strains of endophytic Fusarium oxysporum. Nematology 2013, 15, 101-107. [CrossRef]

63. Su, L.; Shen, Z.; Ruan, Y.; Tao, C.; Chao, Y.; Li, R.; Shen, Q. Isolation of antagonistic endophytes from banana roots against Meloidogyne javanica and their effects on soil nematode community. Front. Microbiol. 2017, 8, 2070. [CrossRef]

64. Hallmann, J.; Quadt-Hallmann, A.; Miller, W.G.; Sikora, R.A.; Lindow, S.E. Endophytic colonization of plants by the biocontrol agent Rhizobium etli G12 in relation to Meloidogyne incognita infection. Phytopathology 2001, 91, 415-422. [CrossRef] [PubMed]

65. Trifonova, Z.; Tsvetkov, I.; Bogatzevska, N.; Batchvarova, R. Efficiency of Pseudomonas spp. for biocontrol of the potato cyst nematode Globodera rostochiensis (Woll.). Bulg. J. Agric. Sci. 2014, 20, 666-669.

66. Istifadah, N.; Pratama, N.; Taqwim, S.; Sunarto, T. Effects of bacterial endophytes from potato roots and tubers on potato cyst nematode (Globodera rostochiensis). Biodiversitas 2018, 19, 47-51. [CrossRef]

67. Muhae-ud-Din, G.; Moosa, A.; Ghummen, U.F.; Jabran, M.; Abbas, A.; Naveed, M.; Jabbar, A.; Ali, M.A. Host status of commonly planted ornamentals to Meloidogyne incognita and management through endophytic bacteria. Pak. J. Zool. 2018, 50, 1393-1402. [CrossRef]

68. Aravind, R.; Eapen, S.J.; Kumar, A.; Dinu, A.; Ramana, K.V. Screening of endophytic bacteria and evaluation of selected isolates for suppression of burrowing nematode (Radopholus similis Thorne) using three varieties of black pepper (Piper nigrum L.). Crop Prot. 2010, 29, 318-324. [CrossRef]

69. Tran, T.P.H.; Wang, S.-L.; Nguyen, V.B.; Tran, D.M.; Nguyen, D.S.; Nguyen, A.D. Study of novel endophytic bacteria for biocontrol of black pepper root-knot nematodes in the central highlands of Vietnam. Agronomy 2019, 9, 714. [CrossRef]

70. Hoang, H.; Tran, L.H.; Nguyen, T.H.; Nguyen, D.A.T.; Nguyen, H.H.T.; Pham, N.B.; Trinh, P.Q.; de Boer, T.; Brouwer, A.; Chu, H.H. Occurrence of endophytic bacteria in Vietnamese robusta coffee roots and their effects on plant parasitic nematodes. Symbiosis 2020, 80, 75-84. [CrossRef]

71. Hallmann, J.; Quadt-Hallmann, A.; Mahaffee, W.F.; Kloepper, J.W. Bacterial endophytes in agricultural crops. Can. J. Microbiol. 1997, 43, 895-914. [CrossRef]

72. Padgham, J.L.; Sikora, R.A. Biological control potential and modes of action of Bacillus megaterium against Meloidogyne graminicola on rice. Crop Protect. 2007, 26, 971-977. [CrossRef]

73. Le, H.T.T.; Padgham, J.L.; Sikora, R.A. Biological control of the rice rootknot nematode Meloidogyne graminicola on rice, using endophytic and rhizosphere fungi, Int. J. Pest Manag. 2009, 55, 31-36.

74. Le, H.T.T.; Padgham, J.L.; Hagemann, M.H.; Sikora, R.A.; Schouten, A. Developmental and behavioural effects of the endophytic Fusarium moniliforme Fe14 towards Meloidogyne graminicola in rice. Ann. Appl. Biol. 2016, 169, 134-143. [CrossRef]

75. Timper, P.; Gates, R.N.; Bouton, J. Response of Pratylenchus spp. in tall fescue infected with different strains of the fungal endophyte Neotyphodium coenophialum. Nematology 2005, 7, 105-110. [CrossRef]

76. Rogers, J.K.; Walker, N.R.; Young, C.A. The effect of endophytic fungi on nematode populations in summer-dormant and summer-active tall fescue. J. Nematol. 2016, 48, 87-94. [CrossRef]

77. Liu, Y.; Ponpandian, L.N.; Kim, H.; Jeon, J.; Hwang, B.S.; Lee, S.K.; Park, S.-C.; Bae, H. Distribution and diversity of bacterial endophytes from four Pinus species and their efficacy as biocontrol agents for devastating pine wood nematodes. Sci. Rep. 2019, 9, 12461. [CrossRef]

78. Munif, A.; Mulyadisastra, S.; Herliyana, E.N.; Pradana, A.P. Endophytic bacterial consortium originated from forestry plant roots and their nematicidal activity against Meloidogyne incognita infestation in greenhouse. Acta Univ. Agric. Silvic. Mendelianae Brun. 2019, 67, 1171-1182. [CrossRef]

79. Ponpandian, L.N.; Rim, S.O.; Shanmugam, G.; Jeon, J.; Park, Y.-H.; Lee, S.-K.; Bae, H. Phylogenetic characterization of bacterial endophytes from four Pinus species and their nematicidal activity against the pine wood nematode. Sci. Rep. 2019, 9, 12457. [CrossRef] [PubMed]

80. Zinniel, D.K.; Lambrecht, P.; Harris, N.B.; Feng, Z.; Kuczmarski, D.; Higley, P.; Ishimaru, C.A.; Arunakumari, A.; Barletta, R.G.; Vidaver, A.K. Isolation and characterization of endophytic colonizing bacteria from agronomic crops and prairie plants. Appl. Env. Microbiol. 2002, 68, 2198-2208. [CrossRef] [PubMed]

81. Siddiqui, Z.A.; Mahmood, I. Role of bacteria in the management of plant parasitic nematodes: A review. Bioresour. Technol. 1999, 69, 167-179. [CrossRef]

82. Kobayashi, D.Y.; Palumbo, J.D. Bacterial endophytes and their effects on plants and uses in agriculture. In Microbial Endophytes; Bacon, C.W., White, J., Eds.; CRC Press: Boca Raton, FL, USA, 2000; pp. 199-233.

83. Yadav, A.N.; Verma, P.; Kour, D.; Rana, K.L.; Kumar, V.; Singh, B.; Chauahan, V.S.; Sugitha, T.; Saxena, A.K.; Dhaliwal, H.S. Plant microbiomes and its beneficial multifunctional plant growth promoting attributes. Int. J. Environ. Sci. Nat. Resour. 2017, 3, 1-8. [CrossRef]

84. Escudero, N.; Lopez-Llorca, L.V. Effects on plant growth and root-knot nematode infection of an endophytic GFP transformant of the nematophagous fungus Pochonia chlamydosporia. Symbiosis 2012, 57, 33-42. [CrossRef]

85. Schouten, A. Mechanisms involved in nematode control by endophytic fungi. Annu. Rev. Phytopathol. 2016, 54, 121-142. [CrossRef] [PubMed]

86. Fadiji, A.E.; Babalola, O.O. Elucidating mechanisms of endophytes used in plant protection and other bioactivities with multifunctional Prospects. Front. Bioeng. Biotechnol. 2020, 8, 467. [CrossRef] 
87. Khan, B.; Yan, W.; Wei, S.; Wang, Z.; Zhao, S.; Cao, L.; Rajput, N.A.; Ye, Y. Nematicidal metabolites from endophytic fungus Chaetomium globosum YSC5. FEMS Microbiol. Lett. 2019, 366, fnz169. [CrossRef]

88. Hasky-Gunther, K.; Sikora, R.A. Induced resistance: A mechanism induced systemically throughout the root system by rhizosphere bacteria towards the potato cyst nematode Globodera pallida. Nematologica 1995, 41, 306.

89. Schafer, K. Dissecting Rhizobacteria-Induced Systemic Resistance in Tomato against Meloidogyne incognita: The First Step Using Molecular Tools. Ph.D. Thesis, Rheinische Friedrich-Wilhelms-Universitat Bonn, Bonn, Germany, 2007.

90. Zhao, J.; Wang, S.; Zhu, X.; Wang, Y.; Liu, X.; Duan, Y.; Fan, H.; Chen, L. Isolation and characterization of nodules endophytic bacteria Pseudomonas protegens Sneb 1997 and Serratia plymuthica Sneb 2001 for the biological control of root-knot nematode. Appl. Soil Ecol. 2021, 164, 103924. [CrossRef]

91. Kumar, V.; Sarma, M.V.R.K.; Saharan, K.; Srivastava, R.; Kumar, L.; Sahai, V.; Bisaria, V.S.; Sharma, A.K. Effect of formulated root endophytic fungus Piriformospora indica and plant growth promoting rhizobacteria fluorescent pseudomonads R62 and R81 on Vigna mungo. World J. Microbiol. Biotechnol. 2012, 28, 595-603. [CrossRef]

92. Varkey, S.; Anith, K.N.; Narayana, R.; Aswini, S. A consortium of rhizobacteria and fungal endophyte suppress the root-knot nematode parasite in tomato. Rhizosphere 2018, 5, 38-42. [CrossRef]

93. Soler, A.; Marie-Alphonsine, P.A.; Quénéhervé, P.; Prin, Y.; Sanguin, H.; Tisseyre, P.; Daumur, R.; Pochat, C.; Dorey, E.; Rodriguez, R.G.; et al. Field management of Rotylenchulus reniformis on pineapple combining crop rotation, chemical-mediated induced resistance and endophytic bacterial inoculation. Crop Protec. 2021, 141, 105446. [CrossRef]

94. Hasky-Günther, K.; Hoffmann-Hergarten, S.; Sikora, R.A. Resistance against the potato cyst nematode Globodera pallida systemically induced by the rhizobacteria Agrobacterium radiobacter (G12) and Bacillus sphaericus (B43). Fund. Appl. Nematol. 1998, 21, 511-517.

95. Strom, N.; Hu, W.; Haarith, D.; Chen, S.; Bushley, K. Corn and soybean host root endophytic fungi with toxicity toward the soybean cyst nematode. Phytopathology 2020, 110, 603-614. [CrossRef]

96. Korkina, L.G. Phenylpropanoids as naturally occurring antioxidants: From plant defense to human health. Cell. Mol. Biol. 2007, 53, 15-25. [PubMed]

97. Bogner, C.W.; Kamdem, R.S.T.; Sichtermann, G.; Matthäus, C.; Hölscher, D.; Popp, J.; Proksch, P.; Grundler, F.M.W.; Schouten, A. Bioactive secondary metabolites with multiple activities from a fungal endophyte. Microb. Biotechnol. 2017, 10, 175-188. [CrossRef]

98. Koepcke, B.; Johansson, M.; Sterner, O.; Anke, H. Biologically active secondary metabolites from the ascomycete A111-95 1. Production, isolation and biological activities. J. Antibiot. 2002, 55, 36-40. [CrossRef] [PubMed]

99. Schwarz, M.; Köpcke, B.; Weber, R.W.; Sterner, O.; Anke, H. 3-Hydroxypropionic acid as a nematicidal principle in endophytic fungi. Phytochemistry 2004, 65, 2239-2245. [CrossRef] [PubMed]

100. Li, G.H.; Yu, Z.F.; Li, X.; Wang, X.B.; Zheng, L.J.; Zhang, K.Q. Nematicidal metabolites produced by the endophytic fungus Geotrichum sp. AL4. Chem. Biodivers. 2007, 4, 1520-1524. [CrossRef] [PubMed]

101. Kwon, H.R.; Son, S.W.; Han, H.R.; Choi, G.J.; Jang, K.S.; Choi, Y.H.; Lee, S.; Sung, N.-D.; Kim, J.C. Nematicidal activity of bikaverin and fusaric acid isolated from Fusarium oxysporum against pine wood nematode, Bursaphelenchus xylophilus. Plant Pathol. J. 2007, 23, 318-321. [CrossRef]

102. Zheng, L.; Li, G.; Wang, X.; Pan, W.; Li, L.; Hua, L.; Liu, F.; Dang, L.; Mo, M.; Zhang, K. Nematicidal endophytic bacteria obtained from plants. Ann. Microbiol. 2008, 58, 569-572. [CrossRef]

103. Hu, Y.; Zhang, W.; Zhang, P.; Ruan, W.; Zhu, X. Nematicidal activity of chaetoglobosin A poduced by Chaetomium globosum NK102 against Meloidogyne incognita. J. Agric. Food Chem. 2013, 61, 41-46. [CrossRef] [PubMed]

104. Liarzi, O.; Bucki, P.; Braun Miyara, S.; Ezra, D. Bioactive volatiles from an endophytic Daldinia cf. concentrica isolate affect the viability of the plant parasitic nematode Meloidogyne javanica. PLoS ONE 2016, 11, e0168437. [CrossRef]

105. Siddiqui, I.A.; Shaukat, S.S. Endophytic bacteria: Prospects and opportunities for the biological control of plant-parasitic nematodes. Nematol. Mediterr. 2003, 31, 111-120.

106. Hallmann, J.; Davies, K.G.; Sikora, R. Biological control using microbial pathogens, Endophytes and antagonists. In Root Knot Nematodes; Perry, R.N., Moens, M., Starr, J.L., Eds.; CAB International: Wallingford, UK, 2009; pp. 380-411.

107. Rabiey, M.; Hailey, L.E.; Roy, S.R.; Grenz, K.; Al-Zadjali, M.A.S.; Barrett, G.A.; Jackson, R.W. Endophytes vs tree pathogens and pests: Can they be used as biological control agents to improve tree health? Eur. J. Plant Pathol. 2019, 155, 711-729. [CrossRef]

108. Dara, S.K. The new integrated pest management paradigm for the modern age. J. Integr. Pest Manag. 2019, 10, 12. [CrossRef] 